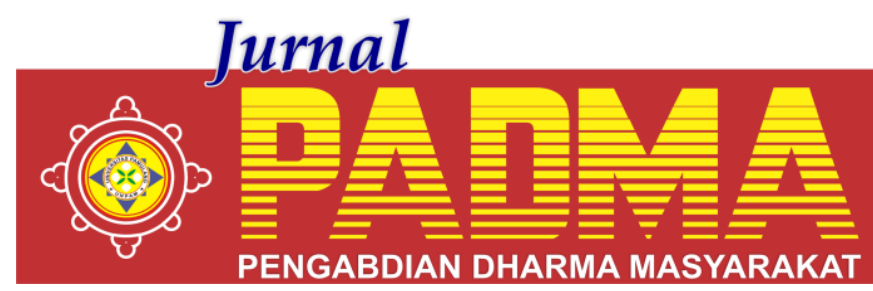

VOLUME 1, NOMOR 2, APRIL 2021

\title{
EDUKASI BAHAYA PORNOGRAFI PADA SISWA SMK MUHAMMADIYAH PARUNG KABUPATEN BOGOR
}

\author{
${ }^{1 *}$ Indra Solihin, ${ }^{2}$ Nurhadi, ${ }^{3}$ Irnida Fara Syahada, ${ }^{4}$ Erwin Suandan, ${ }^{5}$ Klarisa Deo Saputri \\ Universitas Pamulang, Tangerang Selatan, Banten Indonesia \\ *indra62201@unpam.ac.id
}

\begin{abstract}
Abstrak
Apabila dicermati, makapermasalahan yang dihadapi siswa sebagian besar sama, antara lain: (a) Kurangnya pemahaman akan bahaya pornografi, (b) Kurangnya pengawasan Orang tua atas apa yang di konsumsi anak, (c) Terlalu liarnya penjelajahan siswa di situs internet (d) sulitnya memantau apa apa yang di lakukan siswa akan gawai yang digunakan dengan era digital saat ini. Permasalahan pornografi merupakan permasalahan masa depan remaja sehingga harus dipersiapkan dengan sebaik baiknya, guna menghasilkan generasi yang baik tanpa dirusak oleh situs yang tidak bertanggung jawab

Kata Kunci: Bahaya Pornografi
\end{abstract}

Abstract
When examined, the problems faced by students are mostly the same, including: (a) Lack of understanding of the dangers of pornography, (b) Lack of parental supervision of what children consume, (c) Too wild student browsing on internet sites (d) the difficulty of monitoring what students are doing with the devices used in today's digital era. The problem of pornography is a problem for youth's future so it must be prepared properly, in order to produce a good generation without being damaged by irresponsible sites.

Keywords: The Dangers of Pornography.

\section{PENDAHULUAN}

Remaja adalah suatu fase yang harus dialami manusia sebagai individu. Remaja adalah masa peralihan dari masa anak-anak dengan masa dewasa dengan rentang usia antara 12 - 22 tahun, dimana pada masa tersebut terjadi proses pematangan baik itu pematangan fisik, maupun psikolog.

Dalam perkembangannya remaja mengalami perubahan emosional, kognitif, dan psikis, salah satu perubahan yang tidak bisa dihindari adalah motivasi dan rasa keingintahuan yang tinggi terhadap berbagai hal yang menimpa dirinya termasuk masalah-masalah yang berhubungan dengan seksualitas. Kecanggihan teknologi membuat mudahnya mengakses content bermuatan seks yaitu pornografi sehingga banyak remaja yang menikmati hal ini dan menjadi candu. Paparan pornografi pada anak-anak terutama didapat melalui intenet yang diperburuk dengan "lifestyle" dan kurangnya pengawasan, tidak ada komunikasi, tuntutan terlalu tinggi, kekerasan pada anak, tidak tahu potensi anak, serta diskriminasi dari orang tua dan lingkungan dapat memicu remaja untuk dapat terpapar pornografi.

Berdasarkan survey yang dilaksanakan Kemenkes tahun 2017 sebanyak 94\% siswa pernah mengakses konten porno yang diakses melalui komik sebanyak 43\%, internet sebanyak 57\%, game sebanyak $4 \%$, film/TV sebanyak 17\%, Media sosial sebanyak 34\%, Majalah sebanyak 19\%, Buku sebanyak 26\%, dan lain-lain 4\%.

Pornografi sendiri merupakan sketsa, ilustrasi, foto, tulisan, suara, bunyi, animasi, kartun, percakapan, gerak tubuh, atau bentuk pesan lain melalui berbagai bentuk media komunikasi dan atau pertunjukan di muka umum, yang memuat kecabulan atau eksploitas seksual yang melanggar norma kesusilaan (UU No. 44 Th 2008 tentang pornografi). Sudah menjadi rahasia umum bila pornografi dapat menimbulkan kecanduan, candu pornografi menjadi salah satu isu serius di seluruh dunia, termasuk indonesia. Tingkat kecanduan pornografi menurut Skinner 2005 dibagi menjadi :

1. Level 1 : melihat pornografi sekali atau dua kali setahun, paparan sangat terbatas 
2. Level 2 : beberapa kali setiap tahun tetapi tidak lebih dari enam kali, fantasi sangat minimal

3. Level 3 : mulai muncul tanda kecanduan, sebulan sekali, mencoba menahan diri

4. Level 4 : mempengaruhi fokus untuk tugas sehari-hari, beberapa kali dalam sebulan

5. Level 5 : Setiap minggu, berusaha keras untuk berhenti, namun mulai mengalami gejala withdrawal

6. Level 6: Setiap hari untuk memikirkan pornografi, menyebabkan berbagai masalah dalam kehidupan

7. Level 7 : perasaan ketidakberdayaan dan keputusasaan bila tidak melihat pornografi, konsekuensi negatif

Ciri-ciri anak atau remaja yang kecanduan pornografi perlu diketahui oleh orang tua adalah:

1. Sering tampak gugup apabila ada yang mengajaknya komunikasi, menghindari kontak mata.

2. Tidak punya gairah aktivitas, prestasi menurun

3. Malas, enggan belajar dan enggan bergaul, sulit konsentrasi

4. Enggan lepas dari gawainya (gadget), bila ditegur dan dibatasi penggunaannya akan marah

5. Senang menyendiri, terutama dikamarnya, menutup diri

6. Melupakan kebiasaan baiknya.

Seperti halnya narkoba, kecanduan pornografi juga mengakibatkan kerusakan otak yang cukup serius. Pornografi bukan hanya merusak otak dewasa tetapi juga otak anak. Kerusakan otak tersebut sama dengan kerusakan otak pada orang yang mengalami kecelakaan mobil dengan kecepatan sangat tinggi. Kerusakan otak yang diserang oleh pornografi adalah Pre Frontal Korteks (PFC), bagi manusia bagian otak ini merupakan salah satu bagian yang paling penting karena bagian otak ini hanya dimiliki oleh manusia sehingga manusia memiliki etika bila dibandingkan binatang. Bagian otak ini berfungsi untuk menata emosi, memusatkan konsentrasi, memahami dan membedakan benar dan salah, mengendalikan diri, berfikir kritis, berfikir dan berencana masa depan, membentuk kepribadian, dan berperilaku sosial.
Awalnya saat melihat pornografi, reaksi yang ditimbulkan adalah perasaan jijik, hal ini terjadi karena manusia mempunyai sistem limbik, sistem ini pula yang mengeluarkan hormon dopamin untuk menenangkan otak, tetapi dopamin juga akan memberi rasa senang, bahagia sekaligus ketagihan. Dopamin mengalir ke arah PFC, PFC menjadi tidak aktif karena terendam dopamin. Apabila dopamin semakin banyak maka seseorang akan timbul rasa penasaran dan semakin kecanduan melihat pornografi, namun untuk memenuhi kepuasan dan kesenangannya, seseorang akan melihat yang lebih porno / vulgar lagi untuk memicu dopamin yang lebih banyak. Karena terus dibanjiri dopamin, PFC akan semakin mengkerut dan mengecil dan lama-lama menjadi tidak aktif akibanya fungsi dari bagian otak ini semakin tidak aktif.

Akibat dari kecanduan pornografi sangat membahayakan bagi orang yang bersangkutan dan orang-orang di sekitarnya, seperti :

1. Mengubah sikap dan persepsi tentang seksualitas bahwa wanita dan anak-anak hanya merupakan obyek seks saja

2. Meningkatkan eksplorasi seks remaja sehingga dapat terjadi perilaku seks bebas dan perilaku seksual beresiko

3. Mudah berbohong

4. Menurunkan harga diri dan konsep diri

5. Depresi dan ansietas

6. Pendidikan terganggu

7. Terjadi penyimpangan seksual

Hal tersebut tentu saja merusak tatanan norma-norma dalam masyarakat, merusak keserasian hidup keluarga dan masyarakat.

Pornografi merupakan adiksi baru yang tidak tampak pada mata, tidak terdengar oleh telinga, namun menimbulkan kerusakan otak yang permanen bahkan melebihi kecanduan narkoba. Oleh karena itu, diperlukan suatu pembinaan dan pengawasan dari semua kalangan, khususnya untuk anak-anak, remaja dan dewasa muda agar bisa terhindar dari bahaya pornografi yaitu melalui peran aktif orang tua dengan cara:

1. Memberikan perhatian, kasih sayang dan penghargaan kepada anak 
2. Mengenali teman dan lingkungan sekitarnya

3. Melatih anak agar mampu berkata TIDAK terhadap ajakan pornografi

4. Menyepakati aturan yang dibuat bersama dengan anak dalam penggunaan gawai

5. Mendampingi anak ketika mengakses internet

6. Apabila anak ketahuan mengakses situs pornografi, orang tua harus mengajak berdialog dan menjelaskan dampak pornografi

7. Memberikan pemahaman kepada anak tentang internet sehat dan aman

8. Menempatkan komputer di ruang keluarga

9. Memasang aplikasi pengaman pada gawai

10. Memberikan pendidikan seks sesuai dengan usia perkembangan

Apabila remaja sudah mengalami kecanduan pornografi, kerusakan otak yang sudah ditimbulkan dapat dipulihkan melalui berbagai terapi, sedangkan kecanduan yang terjadi dapat dihentikan dengan pendampingan dari orang tua dan keluarga dan apabila diperlukan dapat meminta bantuan psikolog.

Pengabdian kepada masyarakat merupakan pelaksanaan pengamalan ilmu pengetahuan, teknologi dan seni budaya langsung pada masyarakat secara kelembagaan melalui metodologi ilmiah sebagai penyebaran Tri Dharma Perguruan Tinggi serta tanggung jawab yang luhur dalam usaha mengembangkan kemampuan masyarakat, sehingga dapat mempercepat laju pertumbuhan tercapainya tujuan pembangunan nasional.

Siswa SMK Muhammadiyah Parung memiliki permasalahan yaitu bekenaan dengan pronografi. SMK Muhammadiyah Parung berkewajiban membentuk mindset dan ketrampilan peserta didiknya agar mampu bersaing di era milenial saat ini. Salah satunya adalah dengan memberikan workshop mengenai bahaya pornografi. Agar Siswa menjadi generasi yang baik dan berkualitas

Adapun tujuan dari kegiatan pengabdian kepada masyarakat ini adalah untuk memberikan workshop siswa SMK Muhammadiyah Parung memahami dan mampu menghindari hal hal yang berbau pornografi sehingga menjadi generasi yang sehat akan asupan pikiran.

Kegiatan pengabdian kepada masyarakat dari tim dosen dan mahasiswa Universitas Pamulang hadir di SMK Muhammadiyah Parung, serta berbagi pengetahuan dan wawasan dengan bentuk workshop tentang bahaya pornografi. Workshop yang bertujuan untuk dapat menghindari segala sesuatu yang berbau porno dari diri sendiri.

Tim pengusul pengabdian kepada masyarakat berharap respon dan antusiasme, khususnya siswa SMK Muhammadiyah Parung dalam pembahasan bahaya pornografi ini. Sehingga kegiatan pengabdian kepada masyarakat tidak hanya berhenti pada kegiatan workshop ini tetapi dapat berkelanjutan sesuai kebutuhan siswa, terutama yang berkaitan dengan bahayanya pornografi bagi generasi remaja.

Sasaran kegiatan Pengabdian kepada masyarakat (PKM) ini adalah dengan merangkul siswa SMK Muhammadiyah Parung untuk mengikuti kegiatan meningkatkan softskill dengan tema "Edukasi Bahaya Pornografi Pada Siswa Smk Muhammadiyah Parung Kab. Bogor".

\section{METODE}

Dalam kegiatan ini metode yang diterapkan diharapkan dapat memberikan kemudahan kepada para siswa SMK Muhammadiyah Parung. Metode yang digunakan adalah metode diskusi kelompok, sharing, tanyajawab, praktik yang di damping oleh co trainer. Pada metode penjelasan, setiap instruktur menyampaikan materi terkait dan membuat tampilan visual berupa slide power point yang ditampilkan ke layar dengan LCD proyektor.

Instruktur dalam menyampaikan penjelasan juga memasukkan unsur "sharing" atau berbagi pengalaman mengenai penggunaan rencana karir dalam memperkuat motivasi belajar yang telah dimiliki trainer, dengan pertimbangan tersebut diharapkan dapat memberikan gambaran lebih jelas kepada peserta. Pada metodepraktik, peserta berkelompok dan dengan pendampingan trainer mahasiswa bergantian melakukan penyusunan rencana karir dan mensugesti secara bergantian 
berkaitan dengan temannya. Peserta diajarkan bagaiman acara menyusun karir belajar mereka hingga strategi meraih citacita dengan fokus dan terarah, dengan menggunakan rencana karir yang jelas.

\section{HASIL DAN PEMBAHASAN}

Kegiatan Pengabdian Kepada Masyarakat ini berkaitan bahaya pornografi. Hal ini akan sangat berbahaya jika di biarkan, maka akan menjadi generai yang tidak baik dan akan menularkan ketidakbaikan itu kepada generasi selanjutnya dan dengan PKM ini maka para remasja di SMK Muhammadiyah Parung telah mendapatkan apa yang seharusnya mereka fahami yaitu:

1. Betapa bahayanya situs pornografi

2. Cara memblok situs tersebut

3. Menyadarkan dengan hal yang lebih bermanfaat

4. Mengingatkan betapa semua akan merusak masa depan

Group Discussion yang digunakan sebagai model penyampaian materi dirasa sangat efektif, siswa lebih dapat terbuka dalam menyampaikan keresahannya tentang masa depan dengan suasana yang santai dan terbuka. Seluruh perserta diajak mengutarakan permasalahan untuk kemudian dipecahkan bersama-sama. Kebanyakan siswa yang menjadi peserta masih belum memahami bahaya di masa yang akan dating tenga pornografi.

\section{PENUTUP}

Hasil kegiatan PKM di SMK Muhammadiyah Parung berjalan dengan lancar. Siswa terlihat fokus dan antusias. Selain itu memberikan motivasi baru bagi siswa untuk lebih berfikir positif dan tidak mengulangi kebiasaan buruk akan hal pornografi.

\section{DAFTAR PUSTAKA}

Dewa Ketut Sukardi, Pengaantar Pengantar Pelaksanaan Program Bimbingan dan Konseling di Sekolah, RinekaCipta: Jakarta, 2000.

M Catio, D Sunarsi. (2020). Analisa Pengaruh Kompetensi, Disiplin Kerja Dan Motivasi Terhadap Kinerja Guru Pada SMK Sasmita Jaya 1 Pamulang Kota Tangerang Selatan. Equilibrium: Jurnal
Penelitian Pendidikan dan Ekonomi 17 (02), 16-26.

Robert L. Gibson \& Marianne H. Hitchell, Bimbingan dan Konsleing, PustakaPelajar: Yogyakarta, 2011.

Santoso, A. B., Husain, B. A., Supiandi, G., Sudarso, A. P., \& Akbar, I. R. Knowledge Sharing Melalui Motivasi Belajar Dan Pelatihan Bahasa Inggris Pada Yayasan Domyadhu Pamulang. Jurnal Pengabdian Dharma Laksana, 3(2), 106-109.

Sobarna, A., Hambali, S., Sutiswo, S., \& Sunarsi, D. (2020). The influence learning used $\mathrm{ABC}$ run exercise on the sprint capabilities. Jurnal Konseling dan Pendidikan, 8(2), 67-71.

Sunarsi, D., \& Asmalah, L. (2018). Pelatihan Manajemen Pengembangan Diri Bagi Penerima Beasiswa RZIS UGM Dan Dompet Shalahuddin Jogjakarta. Jurnal Pengabdian Dharma Laksana, 1(1), 5160.

Sutirna, Bimbingan dan Konseling Pendidikan Formal, Nonformal dan Informal, (ANDI: Yogyakarta, 2013.

Walgito, Bimo, Bimbingan \& Konseling (Studi dan Karir), ANDI OFFSET: Yogyakarta, 2005.

Y Kadarusman, D Sunarsi. (2020). Pengaruh Strategi Penetapan Harga Terhadap Peningkatan Jumlah Siswa Pada SMK PGRI Balaraja. JS (JURNAL SEKOLAH) 4 (3), 213-221. 